\title{
From devotional aids to antiquarian objects. The prayer books of Medingen
}

For Elizabeth Andersen, ${ }^{1}$

my travel companion on the route of discovery through the Northern German devotional landscape

\begin{abstract}
Prayer books are precious items. In auction catalogues, medieval Books of Hours, Psalters and illuminated miscellanies of prayers and meditations regularly top the price list of antiquarian books on sale. The original reason for the costliness of the books lies in their content: only the best is good enough in the service of God, and the importance attached to inward devotion should be reflected in the outward status of the manuscript. When the prayer books left their original context, the precious character of the manuscripts secured their survival as objects. Prayer books acquired a new significance as antiquarian curiosities for private collectors or as basis for scholarly studies in libraries.
\end{abstract}

A rare insight into this process is provided by the large group of prayer books extant from Medingen, one of the six Lüneburg convents. In the late fifteenth century, Cistercian nuns composed, copied and illuminated manuscripts, for their personal use and the use of their female relatives. Today, more than 50 of these survive in collections all over the world. By tracing the wanderings of manuscripts from convents to libraries, the changing attitude of writers and collectors towards these precious objects also becomes apparent, as shown by the manuscripts' re-working : features incorporated by the nuns themselves, signs of appropriation by antiquarians, and the new significance attached to them by researchers. ${ }^{2}$

I will discuss the production and dissemination of Medingen prayer books, through two major "reading processes", both of which engage with the manuscripts as objects. The first of these uses the books mainly as devotional aids, while the second values them predominately as antiquarian objects; however, these reading processes overlap and intertwine. I would argue, indeed, that late

1 Dutifully and pleasurably my thanks go particularly to Elizabeth Andersen, who not only patiently proofread and improved my English in this paper (and many before), but was also the inspirational "other" in conversations about "Gott und die Welt," Northern Germany, mysticism, devotion, translation and teaching over nearly nine years of adventures shared at the School of Modern Languages in Newcastle. The whole framework of this article could not have been built without her and I am very grateful that our collaboration will continue to thrive. This dedication celebrates a significant July 2016 birthday.

2 The presentation on which this chapter is based was given as a work-in-progress paper during my annual time as Fellow at the FRIAS. I was at that point working on a collective article with students from the University of Connecticut on the two Medingen prayer books now in the Houghton Library, to be published in Harvard Library Bulletin (HHL1 and HHL2). At the same time, I was researching the provenance of a Medingen psalter to be acquired by the Bodleian Library (O4), which subsequently became the focus of my Inaugural Lecture in Oxford in January 2016, online on podcasts.ox.ac.uk, published in Oxford German Studies. The material from these two studies is here recast for the specific argument of the book. All manuscripts are referred to by sigla, which can be found on my website of the Medingen Manuscripts, originally developed in Newcastle with the help of Andres Laubinger, now based at Oxford: medingen.seh.ox.ac.uk. The website also provides an extensive bibliography with links to digitised literature. 
medieval personalised devotional manuscripts can be read as cultural objects throughout their life, from their original production right through to their (post-)modern digitisation. The nuns who produced and personalised their prayer books as an act of devotion were passionate about the material side; precious parchment, colourful illustration and gold provided means of drawing out the importance of the contents. Manuscripts did not lose their ability to inspire prayer and contemplation even when passing through auction houses. Nevertheless, in the early eighteenth century, a major focal shift in the appreciation of these manuscripts occurs; regarded as not contributing to Protestant worship, they become disposable assets from the history of the convent.

The first part of this chapter will therefore deal with Medingen as scriptorium, embracing conventual reform in the late fifteenth century, which stimulated the production of prayer books, through the Lutheran Reformation, which saw a reworking of the manuscripts, up to the Thirty Years War, when they were boxed up. The second part follows the wanderings of the manuscripts after they were sold in the early eighteenth century as they changed hands through collectors, auction houses and libraries.

\section{Prayer Books as Devotional Aids}

As far as we can tell, prayer books were produced in Medingen only from the last quarter of the fifteenth century onwards. The process was triggered by the late medieval devotio moderna in the Netherlands which reached the Northern German convents through the monastic reform movement from Windesheim and Bursfelde (Andersen / Lähnemann / Simon 2014). In 1469, Johannes Busch, the leading figure of the Observant reform emanating from Windesheim, undertook himself the reform of Wienhausen, another of the Lüneburg convents (Mecham 2014). He met with bitter resistance but once the process had been achieved, the Cistercian nuns from Wienhausen took part in the reform of their sister convent Medingen in 1479 - and that met with enthusiasm. The nuns fully embraced the reform and put it into practice. The renewal of the monastic injunction to "work and pray" led to the first of eight stages in the production and dissemination of Medingen manuscripts.

\section{Stage 1: 1478. Model Prayer Books}

The dates of the first two manuscripts show that they were produced, in preparation of the official reform, by the sisters Winheid and Elisabeth von Winsen, who like almost all of the nuns, came from one of Lüneburg's influential patrician families administering the salt production, which provided the income for the convent. Elisabeth added a long Latin poem as epilogue to her psalter, stating that this work had been commissioned by the reform Provost, Tilemann von Bavenstedt, in 1478. As she remarked at the end, the process of devotional production is one of total commitment; it "flows from my innermost heart, written by hand but involving the whole body" (HI2 = Dombibliothek Hildesheim, Ms J 27, fol. 146v). Elisabeth also stressed an aspect which is crucial to the understanding of the Medingen manuscripts as cultural objects, namely that they were not produced by the modular method, with different scribes and illuminators, but with an integrated approach: "As is plainly visible to the eye which searches all: the written word is joined by flowers to make a picture. All this was done and completed by one single handmaiden in the monastery at Medingen" (Ut clare patebit oculo quis cuncta rimabit: scripta cum floribus picturam sic sociamus. Omnia hec fecit et famula sola peregit, $\mathrm{HI}$, fol. 146v). Her skills are obvious in her decoration of the psalter, the result of a carefully planned process. This started with sourcing the parchment, not as readily available as paper, but more durable and with the prestigious pedigree of use for sacred texts over centuries. Many of the Medingen prayer books were written on discarded text that had been scraped 
down, signalling the commitment to reform and renewal. The dictum of the Gospel prologue according to John that the 'word was made flesh' was highlighted by engagement with animal skin as written material. The careful Gothic book script, written in a different style from the pragmatic texts produced through the Abbey's daily business, further set the text apart as sacred.

Elisabeth's psalter, as well as the prayer book written by Winheid, must have served as model manuscripts for the convent because echoes of them can be seen both in the texts and the illustrations produced by the next two generations of sisters in the convent. Particular features, such as the doodle-like word illustrations in the psalters, the staff-less musical notation of vernacular songs, or the invocation of apostles as special patron saints, occur consistently throughout all later manuscripts, making a Medingen manuscript eminently recognisable. It would seem that the abbey did not have a specialised scriptorium, but rather it made the task of every nun to produce her own books a devotional exercise. This led to the second stage, whence the manuscripts of the von Winsen sisters were taken up by the other nuns.

\section{Stage 2: 1479-1526 The Medingen Scriptorium}

The manuscripts produced between the conventual reform of 1479 and the onset of the Lutheran Reformation in 1526 show an astonishing degree of artistic and literary engagement with the model psalter and prayer book. In Medingen, a clear house style of Gothic book script developed, with similar modes of marginal illumination and widespread use of musical notation, well beyond what might be expected of a group of women who had undergone the same schooling. All the manuscripts were linked by the underlying liturgical structure, and a shared pool of quotations, hymns and iconographic conventions. These features and marginal illustrations, showing authoritative figures such as David, Mary Magdalene or Bernard of Clairvaux, were combined with liturgical quotations. Yet no two manuscripts are identical in terms of textual content, layout or illumination. All nuns working on their individual prayer book copies went to the trouble of expanding the stock of liturgical phrases, of existing meditations and available iconography, as they collected additional Latin and Low German texts, composed new meditations and illuminated these compilations with marginal drawings, musical notation, and colourful initials. This form of manuscript production extended to involve lay sisters. Extant is a Low German primer from Medingen (GT3) which shows how book hand was taught as a style also appropriate for devotional writing for those women in the convent unschooled in Latin.

There are no conventional explicits with scribes' names in any of the later Medingen manuscripts, but the nuns occasionally named themselves in prayer formulas. This occurs particularly in a type of book apparently unique to Medingen: prayer books addressed to apostles as personal patrons. In these, the names mentioned in formulas, such as the request to St Bartholomew to 'look favourably on me, your hand-maiden, Barbara Vischkule' (recognosce me famulam tuam Barbaram viskulem LO2 = V\&A National Library of Art MSL/1886/2629, fol. 95r, Lähnemann 2015), match with the generation of nuns who entered the convent after the reform, again all from well-known Lüneburg families with vested interests in the convent, such as the Vischkule or the Elebeke.

Naming in prayers also helps link the scribes of these personal Latin prayer books to devotional manuscripts written in Low German for lay people such as Anna Töbing, née Elebeke, whose prayer book for feast days ( $G O=$ Forschungsbibliothek Gotha: Ms. Memb. II. 84) had presumably been made for her in the convent by one of her three sisters. Furthermore, the authorship of nuns working as scribes can be identified through the calendars preceding the psalters, which named family members to be prayed for, such as Dietrich Hopes' "my most beloved father" whose decease was recorded as 15 December (Obiit Dydericus hopes pater meus amantissimus, 04 = Oxford, Bodleian Library, MS. 
Don. e. 248 , fol. 12 v, Lähnemann 2016). The nun who noted this down can only have been Margarete Hopes, named as choir mistress in 1524, while she was on the election committee for the new abbess. She thus belonged among the younger nuns, to the second post-reform generation, as attested by a letter of indulgence for the convent issued in 1505. She must have been born around 1480 , entering the convent around the age of six in a solemn oblation ceremony as a puella coronata, which allowed her to wear the crown of betrothal to Christ. The girls underwent a rigorous schooling in Latin and the seven liberal arts. One thousand eight hundred letters from that period, archived at the Lüne Abbey, demonstrate the rhetorical skills of the novices, as do contemporary exercise books from Ebstorf Abbey and the textbooks (Schlotheuber 2014). Thorough training in arts and crafts over ten years at Medingen enabled them to compose Latin texts, write in different scripts for books and letters, read music, and sew textiles, before being admitted to the order as professed nuns.

The layout and decoration of the psalter $\mathrm{O} 4$ is not simply a presentation of the text, but also a statement of cultural identity. On the opening page of Psalm 1, Bernard of Clairvaux is figured in white attire, with a gold halo round his tonsured head; he is holding up a quotation from his sermons on the Song of Songs to the effect that whenever the Psalter is chanted, angels will join in (Angeli psallentibus admisceri solent, 04 , fol. 20v, Lähnemann 2016). The nun singing the psalms from this manuscript would therefore be in good company: not only would King David, the author of the psalms, accompany her on his golden harp but, as the founder of her order also assured her through his personal authority, the ranks of the convent should be swelled by choirs of angels. The opening page is thus effectively used to reflect on the nature of singing psalms in a reformed Cistercian convent. The psalters were handbooks in more than one sense: small enough to be carried around in the hand, wherever duty might take her, from cell to choir stall, as well as to the deathbed of sisters in the Abbey, the presence of the physical object would remind the nun of her status.

Most of the manuscripts show signs of this daily engagement with devotion through the medium of the book as object: added prayers, musical annotations, copious corrections. In Margarete Hopes' psalter, nearly half the pages show some form of textual mark-up to correct, explain or update. The most striking example of her revisions is the replacement of two full pages in response to the Lutheran Reformation, which leads us to the third stage in manuscript production.

\section{Stage 3: $16^{\text {th }}$ Century Reformation Relocation \& Reworking}

Duke Ernst of Lüneburg-Brunswick was one of the early supporters of Luther and tried to rally everybody in his Duchy behind the cause. In 1526, he sent a copy of the Low German adaptation of Luther's translation of the New Testament to Medingen, which the Abbess threw into the brewery fire. A thirty-year bitter struggle for spiritual and financial independence followed (Lähnemann in press). As part of this, a considerable group of manuscripts left the convent when the Abbess Margarete von Stöteroggen (1524-1567) fled with them to the Bishop at Hildesheim and deposited them there. The manuscripts of the von Winsen sisters are therefore now in the Cathedral Library at Hildesheim.

The manuscripts of scribes who were still alive stayed in the convent and were adapted to conform to Lutheran dogma; this process seems already to have begun during the time of negotiations since an address to Mary as 'advocata' was erased in the prayer book of Winheid of Winsen (HI1 fol. 35v) which left the convent in 1542 before the agreement was finally reached in 1556. In the settlement, the convent was allowed to continue its monastic life with Latin liturgy, Cistercian habit and communal meals, in exchange for signing a number of dogmatic points, most prominently to partake of both bread and wine during Eucharistic communion, and to abolish the practice of praying for the intercession of saints. That this was followed to the letter can be observed in an apostle prayer book 
from Medingen ( $L O 4=$ National Art Library at the Victoria \& Albert Museum London, Reid 38, Lähnemann 2015) where the word intercessio in relation to St Peter is repeatedly scraped off the parchment. The material consequences of the dogmatic agreement can be observed particularly clearly in Margarete Hopes' psalter. She had added intercessory prayers addressed to John the Evangelist, her personal patron apostle, in the free space between the calendar pages and the psalter proper. She cut out these two leaves and replaced them with two new ones, invoking Christ as intercessor. The Low German prayer, written in a slightly shaky imitation of the former Gothic style, opens with a glued-in red letter with blue pen-flourish in keeping with the style of the manuscript's previous illumination. The paste-down initial might well have been salvaged from the discarded leaves. The object's shape shifted to accommodate the modified devotional culture, but the older form of veneration remained visible. The physical traces of change turn the body of the manuscript into an object literally inscribed with the changing forms of appreciation.

Adding leaves and new material required taking the book block apart. The psalter had been previously bound in boards covered with blind stamped leather, fastened with metal clasps, in the same workshop as the apostle prayer books from Medingen. To keep the binding intact, the leaves were taken out in their gatherings, the two pages inserted and hooked round the existing gatherings. Before the book was glued back together, the fore edge was trimmed since otherwise the extended book block would have slightly protruded over the old cover. Particular care was taken not to damage any text when cutting down the page borders: the textual content of the psalter had precedence over the material neatness of the object. The stitching of a tear in the leather cover, the in-gluing of new end-bands of striped silk, and the parchment patch used to reinforce the last opening, point to a job done by Margarete Hopes herself, rather than a professional bookbinder. The nuns took the material care for their devotional objects into their own hands.

The third stage of engagement with the manuscripts while at Medingen, the re-working of text as a result of the Lutheran Reformation, was in many cases not the last major change in the life of these objects. The current appearance of the books was as often as not influenced by additions of later signs of ownership, of book plates, new bindings, or even, in the case of Margarete Hopes' psalter, a bone plaque applied to the inside of the cover. This brings us to the second major part of the Medingen prayer books' cultural history, their dissemination as antiquarian objects.

\section{Prayer Books as Antiquarian Objects}

The nuns had crossed the threshold of the Lutheran Reformation with minimal changes in their devotional routine. They retained the Cistercian habit until 1605 . The breaking point with the medieval tradition of worship embodied in the manuscripts seems rather to have been the Thirty Years War (1618-48), when the abbey's treasures were boxed up. Later, costly and authoritative objects such as the Abbess's silver crozier were taken out and once again given pride of place, but the prayer books had become obsolete; under Abbess Katharina Priggen (1681-1706) the liturgical commemoration of saints' days had ceased, triggering a new phase in the life of these manuscripts.

\section{Stage 4: $18^{\text {th }}$ Century Precious Objects}

The earliest attested manuscript to have left the convent was a Low German prayer book (GT1 = Universitätsbibliothek Göttingen: Theol. 242). This bears a note on the front page stating that it was given by the Abbess Anna von Laffert (1720-1721) to the librarian Daniel Eberhard Baring. Such a record indicates a new outside interest in the manuscripts, which was to be used on a larger scale by the next Abbess. The local Minister, Johann Ludolf Lyßmann (1685-1742), noted in his Historical 
Account of the Origin, Growth and Fate of Medingen Abbey, in the Duchy of Lüneburg (Historische Nachricht von dem Ursprunge, Anwachs und Schicksalen des im Lüneburgischen Herzogthum belegenen Closters Meding, Halle 1772) that the Abbess Katharina von Stöteroggen (1722-1741) "substantially increased the convent's income by selling, to the convent's advantage, many superfluous precious objects that had been kept in boxes since the Thirty Year-War, and turned the money into principle. She served God with sincerity and set an example to all the convent womenfolk in observing monastic regulations as well as true divine service..." (vermehrete die Einkünfte des Closters dadurch beträchtlich, daß sie viel unnöthige kostbare Sachen, welche seit dem dreyßigjährigen Kriege in Kasten eingepackt gestanden, dem Closter zum Besten verkaufte, und das Geld zu Capitalien machte. Sie dienete Gott mit redlichem Herzen, und führete die sämtliche Conventualinnen so wol zu Beobachtung der Closterordnungen, als des wahren Gottesdienstes an, ... p. 173). The manuscripts which had remained in the Abbey through the Reformation period, namely those of which the scribes had still been actively using them at that point, were now sold in batches, as the group of apostle prayer books in Hamburg $(\mathrm{HH} 3-\mathrm{HH} 8)$ shows. Previously, the criterion for removing manuscripts from the Abbey of Medingen had been based on personal connections, as when private copies had been sent to lay women. From then on, parchment and illuminations became commodities, precious items to be traded to curious collectors.

The enterprising Abbess Katharina von Stöteroggen came from the same patrician Lüneburg family as the abbess Margarete von Stöteroggen, who had taken a batch of the Medingen manuscripts from the convent to Hildesheim during the Reformation period in order to safeguard her convent's devotional heritage. Whereas for her Protestant successor the dogmatic value of the medieval manuscript production had become dubious and unfit for "true divine service", the manuscripts now acquired new significance and value as items of antiquarian interest and monetary investment. They also became pretty keepsakes and handy, pocket-sized gifts with a regional touch, to be circulated amongst like-minded collectors. In the Easter prayer book now in Copenhagen, a note states that this was given to Olaus Heinrich Moller (1717-1792) by his "most beloved brother" Bernard Moller in 1737, the year he went from Flensburg to Copenhagen to work as a tutor (In bibliothecam Olai Henrici Molleri Flensburgo Cimbri Hamburgi A.D.C.N. MMCCXXXVII d. XXIIII Aprilis ex donatione Fratris unici. dilectiss. optimi, Bernhardi Mollerj peruenit, $\mathrm{K} 2$ = Royal Library Copenhagen: Ms Thott $120-8^{\circ}$, fol. 251v). Their father was Johannes Moller, the renowned biographer of Northern Germany, and, in his wake, both sons seem to have collected anything and everything of regional and historical interest.

\section{Stage 5: $19^{\text {th }}$ Century "Alterthümer" and German Studies}

One of the manuscripts exported to Hildesheim (HI3 = Stadtarchiv Hildesheim: Best. 52 Nr. 379) had returned to devotional use in the seventeenth century, when it was passed on to English Benedictines taking residence in the former monastery at Lamspringe (Lähnemann in press). As a Catholic institution, these were affected by early nineteenth century secularisation. However, rather than returning to Medingen, the monastic house from which they originally came, the Lamspringe manuscripts were brought to libraries and archives at Hildesheim. The prayer books had become part of the archival paper trail for documenting the Abbey's history, of equal value to charters or letters.

Secularisation would also have affected private use of manuscripts, at least indirectly. The early fifteenth century Dutch bone plaque set inside the front cover of Margarete Hopes' psalter, showing Pilate washing his hands, presumably came from a dismembered reliquary. In the early nineteenth century, the antiquarian market, especially in the Rhineland, was awash with broken-up monastic goods, and an antiquarian will probably have combined this vestige with the Medingen psalter. 
Adding the little carved panel to the psalter imitated the covers of representational medieval manuscripts with their costly bindings, including ivory, thus enhancing its value.

There was a second wave of antiquarianism in the nineteenth century, when the manuscripts initially bought directly from the convent were sold on to other private owners or institutions, thus participating in European knowledge exchange. Once in circulation, some Medingen manuscripts changed hands several times during that period, notably those now kept in British institutions. They passed through different German and British auction houses, before British collectors acquired the then fashionable, prettily bound and well-preserved continental illuminated parchment books. This was especially the case as the number of German medieval manuscripts and objects in circulation dramatically increased, due to the Napoleonic secularisation of most German monastic foundations in the early years of the nineteenth century - a fate the Lüneburg convents only narrowly escaped. In the nineteenth century sales, it was rarely the devotional content, but rather the materiality of the manuscript that attracted the buyers. For example, the apostle prayer book written by and for Barbara Vischkule in honour of St Bartholomew (LO2), has an auction mark from the Manchester Art Treasures Exhibition in 1857. The Victoria and Albert Museum, keen to expand its holding in samples of medieval art, bought it at this occasion, alongside a large range of material related to arts and crafts. That it was valued by the $V \& A$, mainly because of the fine tooling of the leather cover, is clear from its inclusion in the 1894 catalogue of Bookbindings and Rubbings of Bindings in the Victoria and Albert Museum (p. 35) by W.H. James Weale.

Prompted by increasing antiquarian interest within nineteenth-century Germany, the quest for "germanische Altherthümer", other Medingen manuscripts in private ownership were now studied. Excerpts from the Low German poetic interludes, interspersed amongst Latin meditations in the Medingen prayer book owned by a private collector (HHL2 = Cambridge (Mass.), Harvard Houghton Libr., MS Lat 440), were edited by one of the most notable Germanists of the nineteenth century, the librarian, poet and medievalist Heinrich Hoffmann von Fallersleben (1798-1874). In his autobiography Fallersleben relates how, during the 'gold-rush' days of early German Studies, he tried to stay one step ahead of other academics and competing colleagues, in the search for literary fragments from the German Middle Ages. In 1837, he first consulted an Easter prayer book in Latin and Low German from Medingen (HV1 = Staats- und Universitätsbibliothek Hannover Ms. 75), as noted by the librarian in Hanover on a piece of paper inserted into the manuscript. Hoffmann von Fallersleben edited the poems from HHL2 in the recently launched periodical Germania. Vierteljahrsschrift für deutsche Alterthumskunde. Editing this, Franz Pfeiffer cross-referenced a footnote to another Medingen manuscript, Winheid's model prayer book (HI1). Increased philological and textual reading of manuscripts thus led to the establishment of a corpus of devotional manuscripts, allowing for their later study as a body of connected cultural objects.

In the course of the century, further manuscripts were added in by other Germanists. Significantly texts from the Medingen prayer books figure prominently in the first issues of the three oldest scholarly periodicals for German Studies, Franz Pfeiffer's Germania, Moriz Haupt's Zeitschrift für deutsches Alterthum, and the journal of the Society for Low German Studies, at the very moment Germanistik was emerging as a philological and patriotic discipline. Here we deal with whole clusters of first generation Germanist pioneers - librarians, school teachers, scholars - taking a close interest in the Medingen manuscripts, as part of the German nation's linguistic and literary heritage that extended across Northern and Southern Germany. 


\section{Stage 6: $20^{\text {th }}$ Century Liturgical Revival \& Musicology}

In the twentieth century, these initial explorations with serendipitous cross-referencing were systematised by increasingly specialised disciplines for the study of medieval manuscripts, with codicology, linguistics and musicology leading the way. In the first decades of the twentieth century, Carl Borchling's Reiseberichte set out to map and identify Middle Low German texts, through the examination of library lists within the whole of the former Low German speaking area, extending as far north as Copenhagen. In four large instalments (1898, 1900, 1902, 1913), he undertook a comprehensive survey for the Göttingen Academy.

The label "Medingen" was first established by the musicologist Walther Lipphardt, who did more than anyone in the twentieth century to establish the corpus of Medingen manuscripts in an (unpublished) type-written catalogue (finished in 1971) to join the central manuscript catalogue of German hymns (Zentraler Handschriftenkatalog des Deutschen Kirchenlieds). At the same time, however, he severely obscured the character of the newly established group by misdating most of the material, as the programmatic title of his catalogue entry, Handschriften aus Medingen 12901550, shows. His misconceptions of a scriptorium, deemed to have existed from the late thirteenth to the early sixteenth centuries, were reinforced by the linguist Axel Mante, who in 1960 edited the Easter part of the two, entirely Low German, Medingen prayer books at Trier (T1 = Bistumsarchiv Trier Ms. I 528 and T2 = Bistumsarchiv Trier Ms. I 529), mistaking the idiosyncratic style of the nuns' untutored writing for archaic language (their education had been in Latin rhetoric after all) and dating the Low German dialect from the fourteenth century. Similarly, based on the different stylistic qualities of the manuscript illuminations, the art historian Brigitte Uhde-Stahl was persuaded by Lipphardt's assumption that the manuscripts were products of a long-lasting scriptorium yielding occasional manuscripts from the late thirteenth to the early sixteenth centuries, rather than concentrated in two generations between 1478 and 1526, as we now know. The myth of the manuscripts' dating was only dispelled by Gerhard Achten at the end of the twentieth century (Achten 1987). However by then it was too late: both the Catholic (Gotteslob) and Protestant (Evangelische Gesangbuch) hymn books had listed Medingen manuscript as a "thirteenth century" source for some of the songs inserted in their collections, such as 'Gelobet seist du, Jesu Christ' or 'Wir wollen alle fröhlich sein'.

What happened to the manuscripts themselves in the twentieth century? As far as we know, the first manuscript to travel outside Europe came to Dom Edmond Obrecht (1825-1935), the Abbot of Gethsemani Trappist monastery in the United States (New Haven, Kentucky), by way of the Danishborn Chicago book dealer Jens Christian Bay (1871-1962), at some point during the first decades of the twentieth century. Obrecht himself documents this in a typewritten note he glued on top of the parchment pastedown. A mix of antiquarian Latin, value judgement, semi-informed historic speculations, personal touch and keen interest in all things Cistercian, shows a special form of engagement with the manuscript, bringing it back into the monastic setting from which it originated: "Preces latinae Monialis Cisterciensis. MS. on paper of the end of the XV century. In Latin, written by a Flemish Cistercian nun or nuns, as it seems to be in two different writings. This MS. contains many pious prayers; folio 1-63 on the Vigil of Easter Sunday. 63-243 on Easter Sunday. 243-360 on the vigil and feast of the Assumption of our Blessed Mother. 380 to end (some pages appear to be missing) about the Dedication of the Church. When well studied the text shows that the MS. was written by a nun, as she calls herself in many places "sponsa". The nun was Flemish, as we find some words in that language in several places (see fol. 142, Osterdach and preceding ones also 230) And that the nun was a Cistercien [sic] is shown especially on fol. 350 "secundum ordinem Cisterciensem" Gift from our good friend, Mr. J. Christian Bay, Chicago III." 
The manuscript is currently on deposit at the Institute of Cistercian Studies at the University of Western Michigan (KAL = Obrecht Collection MS 23) and was, after the Marian prayer book now in Harvard (HHL1 = Cambridge (Mass.), Harvard Houghton Libr., MS Lat 395), the second manuscript from the convent to be digitised. This presents the rare case of a manuscript returning to a monastic setting having passed through private lay ownership. Equally interesting, research shows that Fr. Chrysogonus Waddell (OCSO, 1930-2008), retaining the manuscript after the death of the Abbot, published a long article on it, the only modern theological discussion on the nuns' devotional writing. His readings would have delighted the nuns, who had pleaded in vain with their Order, after its reform, to be given a permanent Cistercian confessor. His article testifies to their astonishing wealth of theological and liturgical knowledge, despite (or perhaps rather because of) his slight interest in the German historical background of the fifteenth century: indeed he did not see the devotion displayed in the meditations as something 'medieval' but as a living document of faith.

The manuscripts that found their way into public ownership in the nineteenth century tended to stay there, whereas those in private lay ownership became increasingly institutionalised. Their paths mirror the upheavals of German politics. This is especially true for Marian prayer book HHL1, which had been in the von Schenck family library at Flechtingen Castle near Magdeburg. The family was expropriated without compensation when the area became part of the Soviet Occupation Zone. Parts of the library, recognisable by the ownership mark Schenck'sche Fidei-Kommiss-Bibliothek, were sold or transferred to the Bibliothek des Historischen Museums in Magdeburg, where the manuscript was kept with the shelf mark Bi (for Bibliothek des Kunstmuseums) 105. This would change after German re-unification, which brings us into the twenty-first century.

\section{Stage 7: $21^{\text {st }}$ Century Internationalisation \& Digitisation}

In 2003, the prayer book held in Magdeburg was the first Medingen manuscript to change hands in the twenty-first century, when it was given back to the von Schenck family in fulfilment of claims for restitution, according to the Equalisation of Burdens Act. In 2004, the manuscript was sold as part of the library by the auction house Hauswedell \& Nolte in Hamburg. In 2006, the Houghton Library purchased and soon digitized it - making it the first of the Medingen manuscripts to be available online. The reason for the rapid path from auction to digitisation lies in the twenty-first century's markedly increased interest in female monasticism, as evidenced by exhibitions such as Krone und Schleier (exhibition in Bonn and Essen in 2005, published in English as Crown and Veil). The title given to the exhibition, which included a number of manuscripts, alongside such items as statues, textiles and whole architectural arrangements, showed a new take on textual heritage embedded in cultural history, in a way that also led to reading prayer books as embodiments of wider devotional practice.

For a look at monastic culture in a wider context, the Protestant abbeys of Lower Saxony were particularly appropriate since many of them, particularly Lüne, Ebstorf, Wienhausen, still contained within their medieval architecture the very trappings of the nuns' life that had given rise to producing the devotional books in the first place. Indeed, my own approach to the books sprang from attempting to identify quotations used by Medingen nuns, in an unusual textile they had produced for one of the parish churches belonging to the monastery. The Wichmannsburger Antependium is a three metre wide patchwork of cloth and sewn-on parchment text scrolls. After reporting that I had seen the textile in the Kestner-Museum in Hanover, and discovered that the text snippets had not been identified, Burghart Wachinger, main editor of the Verfasserlexikon, invited me to write half a column for the final volume of this comprehensive dictionary of medieval German texts (Lähnemann 2004 A scholarship year in Oxford let me turn this into an article for Oxford German Studies (Lähnemann 2005) and work on the two manuscripts from Medingen in the Bodleian Library. Becoming more and more fascinated by the complex texts with their multi-layered theological and 
visual references, and with a recommendation from Nigel F. Palmer, who had commissioned the article, I was contacted by Hans-Walter Stork, keeper of manuscripts at the Staats- und Universitätsbibliothek Hamburg, who had identified a group of five prayer books dedicated to different apostles. All displayed similar features to the known Medingen manuscripts, among the asyet-uncatalogued octavo manuscripts in the stacks. In 2007, Stork curated an exhibition around this discovery (its catalogue is still to be published) under the title Von Frauenhand. Further identifications of Medingen manuscripts snowballed from there. in January 2008, Katharina Georgi identified another apostle prayer book, the previously mentioned LO2 acquired by the V\&A, from a photograph in the Courtauld Institute, while looking for illuminated prayer books for her dissertation. In 2008, Ulrike Hascher-Burger published a catalogue of all manuscripts with musical notations from the Lüneburg convents, as basis for a performance project, producing a number of CDs by the ensemble devotio moderna, led by Ulrike Volkhardt.

At the same time, the above mentioned Institute for Cistercian Studies started a digitisation campaign, to make the liturgical and codicological scholarship of Fr. Chrysogonus Waddell more accessible to the numerous scholars working on the collection from Gethsemani Abbey deposited in Kalamazoo. The newly accessible material included back numbers of the journal Liturgy, initiated by Waddell in 1966 as an unofficial liturgical bulletin after Vatican II. He himself had contributed a large number of the articles, among them the above-mentioned theological discussion of KAL (Waddell 1987). This article came to my attention when I searched for the explicit, mentioned by Heinrich Hoffmann von Fallersleben in his publication on "Low German Easter Rhyme", since the identical final rhyme appears in Latin within the manuscript Fr. Chrysonogus Waddell had quoted. After checking with the Institute's librarian, Sue Steuer, I realised that I had not chanced upon the lost Hoffmann manuscript, but on yet another Easter prayer book from Medingen. I published this fact, and the quest that had led to its discovery, in Medingen's regional newspaper, Uelzener Allgemeine Zeitung, whose culture editor, Horst Hoffmann, turned a colourful article out of it for the monthly supplement Der Heidewanderer (July 2013) and allowed me to post it under open access on my website. There it was discovered by the cataloguer active for Textmanuscripts.com in trying to identify an unknown prayer book which the auction house Les Enluminures had just acquired from another auction house in Brussels. The lost manuscript described by Hoffmann was thus finally identified, despite Devroe \& Stubbe's somewhat misleading description of lot 1071, in their 17 November 2012 catalogue, as a "rustic but thoroughly charming Easter liturgy from Westphalia".

When the Houghton Library purchased it in 2014, I presented my findings at a talk in Harvard in September 2014, Laura Light from Les Enluminures being present. Subsequently she sent me photographs, for the authentication of a Psalter on which she was working for an exhibition on 'Women and their Books' (Light 2015). This turned out to be one of the latest Psalters written in Medingen (O4), by the 16th century Choir mistress Margarete Hopes, the last to continue the tradition of Psalter production initiated by Elizabeth of Winsen in 1478. This discovery coincided with Beate Braun-Niehr's identification in Göttingen of yet another Medingen Psalter (GT4 = Staats- und Universitätsbibliothek Göttingen: $8^{\circ} \mathrm{Cod}$. Ms. theol. $217 \mathrm{Cim}$.), in the same magazine as GT1, the prayer book given to Daniel Eberhard Baring in 1722, i.e. the very first manuscript to leave Medingen as an "antiquarian" object.

Taken together, the production and dissemination of psalters provide fascinating insights into the highly developed devotional culture that flourished at Medingen before the Lutheran Reformation, and the manner in which this has shaped the survival and appreciation of these books as cultural objects. The convent survived, as did the manuscripts, and in fact is still going strong 
(http://www.kloster-medingen.de), bearing testimony to the monastery's rich medieval heritage spread across the world.

What does this tell us about reading prayer books as cultural objects? Sequential analysis of the seven stages reveals recurring patterns. Akin to Shakespeare's seven ages in Jaques's speech likening the world to a stage, the life of the manuscripts forms a "strange eventful history" (As You Like It, II, 7) during which the conditions of their creation shaped their later transformations. Through devotional interpretation of materiality, their production history resonates even within the business world of auction houses. The twenty-first century's readings need to react - positively or negatively to the nineteenth century's predominantly Germanist gaze and Protestant historiographical interpretations of these objects.

Late medieval Reform during the second half of the fifteenth and the first half of the sixteenth centuries was perhaps the most fertile period for producing complex book objects. The threshold phase (Schwellenzeit) between late medieval and early modern Germany provided a window of opportunity in that manuscript production became free to generate new meaning through the establishment of printing. The nuns of Medingen thus mediated between a pre-Lutheran past of representative manuscript production and a post-Reformation future which re-evaluated medieval heritage. Exploring layers of meaning that have been added to these extraordinary products over half a millennium allows us to reflect on the changeable nature of engaging not just with medieval manuscripts but with books as objects in a broader sense.

\section{Bibliography}

Only articles and books referred to by short title in the article are listed. A full bibliography for the Medingen Manuscripts is on the website medingen.seh.ox.ac.uk.

Achten, Gerard. 1987. "De Gebedenboeken van de Cistercienserinnenkloosters Medingen en Wienhausen." Miscellanea Neerlandica 3:173-188.

Akademiebeschreibungen: online at the Handschriftenarchiv of the Berlin-Brandenburgische Akademie der Wissenschaften. http://www.bbaw.de/forschung/dtm/HSA/hsa-index.html. Last accessed 18 July 2016.

Andersen, Elizabeth, Henrike Lähnemann, and Anne Simon, eds. 2014. A Companion to Mysticism and Devotion in Northern Germany in the Late Middle Ages. Leiden: Brill.

Bartsch, Karl. 1879. "Mittelniederdeutsche Osterlieder." Jahrbuch des Vereins für niederdeutsche Sprachforschung 8:46-54.

Becker, Peter Jörg, and Anne-Beate Riecke, eds. 2003. Aderlaß und Seelentrost. Die Überlieferung deutscher Texte im Spiegel Berliner Handschriften und Inkunabeln. Eine Ausstellung der Staatsbibliothek zu BerlinPreußischer Kulturbesitz. Ausstellungskataloge der Staatsbibliothek zu Berlin-Preußischer Kulturbesitz, N.F. 48. Mainz: Zabern.

Borchling, Conrad. 1899. "Mittelniederdeutsche Handschriften in Norddeutschland und den Niederlanden (Reiseberichte I)." Nachrichten von der Königl. Gesellschaft der Wissenschaften zu Göttingen. Geschäftliche Mittheilungen aus dem Jahre 1898 79-316.

Braun-Niehr, Beate. In press. "Ein lateinisches Psalterium aus dem Zisterzienserinnenkloster Medingen (Staatsbibliothek zu Berlin-Preußischer Kulturbesitz, Ms. theol. lat. oct. 189)." In Handschriften aus Kloster Medingen, edited by Hans-Walter Stork. Hamburg: Staats- und Universitätsbibliothek.

Bynum, Caroline Walker. 2015. "Crowned with Many Crowns. Nuns and Their Statues in Late Medieval Wienhausen." Catholic Historical Review 101:1. Centennial Issue, edited by Maureen C. Miller, 17-39.

Einbanddatenbank: hist-einband.de. Search for Zisterzienserinnenkloster Medingen in the category Werkstatt. 
Georgi, Katharina. 2013. Illuminierte Gebetbücher aus dem Umkreis der Nürnberger Pleydenwurff-Wolgemut Werkstatt. Petersberg: Imhof.

Hamburger, Jeffrey, and Susan Marti, eds. 2005. Crown and Veil: Female Monasticism from the Fifth to the Fifteenth Centuries. Translated by Dietlinde Hamburger. New York: Columbia University Press (English translation of Krone und Schleier. 2005).

Handschriftencensus: http://www.handschriftencensus.de/werke/248. Online database of German manuscripts. Entry 'Medinger Gebetbücher.' Last accessed 18 July 2016.

Hascher-Burger, Ulrike, and Henrike Lähnemann. 2013. Liturgie und Reform im Kloster Medingen. Edition und Untersuchung des Propst-Handbuchs Oxford, Bodleian Library, MS. Lat. liturg. e. 18 (Spätmittelalter, Humanismus, Reformation 76). Tübingen: Mohr Siebeck.

Hascher-Burger, Ulrike. 2008. Verborgene Klänge. Inventar der handschriftlich überlieferten Musik aus den Lüneburger Frauenklöstern bis ca. 1550. Mit einer Darstellung der Musik-Ikonographie von Ulrike Volkhardt. Hildesheim, Zürich: Olms.

Hoffmann von Fallersleben, Heinrich. 1857. "Niederdeutsche Osterreime.” Pfeiffers Germania 2:164-7.

Homeyer, Joachim. 1988. Kloster Medingen 1788-1988. 200 Jahre Neubau. Kleine Beiträge zum Jubiläum. Uelzen: Becker.

Krone und Schleier. 2005. Krone und Schleier. Kunst aus mittelalterlichen Frauenklöstern. Katalogbuch, edited by Kunst- und Ausstellungshalle der Bundesrepublik Deutschland und Ruhrlandmuseum Essen. Munich: Hirmer.

Lähnemann, Henrike. In press. "Der Medinger 'Nonnenkrieg' aus der Perspektive der Klosterreform. Geistliche Selbstbehauptung 1479-1554." Ons gheestelijk erf. Special issue. 1517-1545: The Northern Experience. Mysticism, Art and Devotion between Late Medieval and Early Modern. Antwerp Conference 2011, edited by Kees Scheepers.

Lähnemann, Henrike. 2016. “The Materiality of Medieval Manuscripts.” Oxford German Studies 45:121-41.

Lähnemann, Henrike. 2015. "Saluta apostolum tuum. Apostelverehrung in Kloster Medingen." In Weltbild und Lebenswirklichkeit in den Lüneburger Klöstern, edited by Wolfgang Brandis and Hans-Walter Stork, 4164. Berlin: Lukas.

Lähnemann, Henrike. 2014. "Bilingual Devotion in Northern Germany: Prayer Books from the Lüneburg Convents." In A Companion to Mysticism and Devotion in Northern Germany in the Late Middle Ages, edited by Elizabeth Andersen, Henrike Lähnemann, and Anne Simon, 317-41. Leiden: Brill.

Lähnemann, Henrike. 2013. "Medinger Nonnen als Schreiberinnen zwischen Reform und Reformation” and "V.28 Ornat für eine Engelsskulptur." In Rosenkränze und Seelengärten. Bildung und Frömmigkeit in niedersächsischen Frauenklöstern, edited by Britta-Juliane Kruse, 37-42. Wolfenbüttel: Herzog August Bibliothek.

Lähnemann, Henrike. 2005. “'An dessen bom wil ik stighen'. Die Ikonographie des Wichmannsburger Antependiums im Kontext der Medinger Handschriften." Oxford German Studies 34:19-46.

Lähnemann, Henrike. 2004. “Wichmannsburger Antependium.” In Verfasserlexikon, edited by Burghart Wachinger. Second edition, vol. 11 (Nachtragsband), 1655-1656. Berlin: De Gruyter.

Light, Laura. 2015. Women and the Book in the Middle Ages and the Renaissance. Introduction by Anne Winston-Allen. Preface by Sandra Hindman. New York: Les Enluminures. Online http://www.lesenluminures.com and http://www.textmanuscripts.com/.

Lipphardt, Walther. 1972. "Niederdeutsche Reimgedichte und Lieder des 14. Jahrhunderts in den mittelalterlichen Orationalien der Zisterzienserinnen von Medingen und Wienhausen." Niederdeutsches Jahrbuch 95:66-131. 
Lipphardt, Walther. 1971. “Handschriften aus Medingen 1290-1550." Manuskript für den Zentralen Handschriftenkatalog des Deutschen Kirchenlieds, 1. Serie, 1971 abgeschlossen. Unpublished typescript.

Lyßmann, Johann Ludolf. 1772. Johann Ludolf Lyßmanns Historische Nachricht von dem Ursprunge, Anwachs und Schicksalen des im Lüneburgischen Herzogthum belegenen Closters Meding, dessen Pröbsten, Priorinnen und Abbatißinnen, auch fürnehmsten Gebräuchen und Lutherischen Predigern \&c. nebst darzu gehörigen Urkunden und Anmerkungen. Halle: Gebauer.

Mante, Axel. 1960. Ein niederdeutsches Gebetbuch aus der 2. Hälfte des XIV. Jahrhunderts (Bistumsarchiv Trier, Nr. 528). Lunder germanistische Forschungen 33. Lund: Lund University.

Mecham, June L. 2014. Sacred Communities, Shared Devotions. Gender, Material Culture, and Monasticism in Late Medieval Germany. Turnhout: Brepols.

Müller, Joseph Godehard. 1876. “Nachricht über die Bibliothek des Gymnasii Josephini und die auf derselben vorhandenen Handschriften und alten Drucke." In Bischöfliches Gymnasium Josephinum ... zu Hildesheim. Programm für das Schuljahr 1875-1876, 1-21. Hildesheim: Druck der August Lax'schen Buchdruckerei.

Müller, Wilhelm. 1841. “Osterlied."Zeitschrift für deutsches Alterthum 1: 546-47.

Ruh, Kurt, and Burghart Wachinger, eds. 1978-2004. Verfasserlexikon. Die deutsche Literatur des Mittelalters, begründet von Wolfgang Stammler. Fortgeführt von Karl Langosch. 2., völlig neu bearbeitete Auflage unter Mitarbeit zahlreicher Fachgelehrter. Berlin: De Gruyter.

Schlotheuber, Eva. 2014. "Intellectual Horizons: Letters from a Northern German Convent." In A Companion to Mysticism and Devotion in Northern Germany in the Late Middle Ages, edited by Elizabeth Andersen, Henrike Lähnemann, and Anne Simon, 343-72. Leiden: Brill.

Stammler, Wolfgang. 1925. “Die Bedeutung der mittelniederdeutschen Literatur in der deutschen Geistesgeschichte." Germanisch-Romanische Monatshefte 13:422-50.

Stork, Hans-Walter. 2013. "Handschriften des ehemaligen Zisterzienserinnenklosters Medingen zur Zeit der Klosterreform im 15. Jahrhundert und in nachreformatorischer Zeit." In Evangelisches Klosterleben. Studien zur Geschichte der evangelischen Klöster und Stifte in Niedersachsen, edited by Hans Otte, 33760. Studien zur Kirchengeschichte Niedersachsens 46. Göttingen: Vandenhoek \& Ruprecht.

Uhde-Stahl, Beate. 1978. "Figürliche Buchmalereien in den spätmittelalterlichen Handschriften der Lüneburger Frauenklöster." Niederdeutsche Beiträge zur Kunstgeschichte 17:25-60.

Waddell, Fr. Chrysogonus (OCSO). 1987. "The Vidi Aquam and the Easter Morning Procession: Pages from the Prayerbook of a Fifteenth-Century Cistercian Nun." Liturgy 21/3:3-56.

Weale, William H. James. 1894. Bookbindings and Rubbings of Bindings in the Victoria and Albert Museum. London: H. M. Stat. 